JOHN WEISS

\title{
DIALECTICAL IDEALISM AND THE WORK OF LORENZ VON STEIN
}

Dialectical idealism as applied to social theory may be provisionally defined as an attempt to explain the evolution of Western society through the use of dialectical forms which rely upon the presumed motive power of spiritual, mental, or ideal forces. These forces are presumed to "realize themselves" in the historical process. Hegel and Fichte, of course, first made such concepts familiar. The mighty influence of Marx and dialectical materialism, which kept the form but not the idealism of the Hegelian dialectic, has accounted for a lasting eclipse of interest in this earlier form of dialectical social thought. It is at least partly a symptom of this general decline of interest in dialectical idealism that the work of Lorenz von Stein has become, until quite recently, all but forgotten to modern scholarship. ${ }^{1}$

German idealism was, after all, the great seminal force in nineteenth century social and historical thought. And Lorenz von Stein was one of the first and (barring Marx and Engels) perhaps the most able of those who applied Hegelian categories to the study of society and the social process. Furthermore, Stein's work is interesting to the student of German intellectual history, because it sheds much light on the themes and assumptions which were held by those young German intellectuals of the Vormärz who created, out of German idealism and their own revolutionary hopes, the tradition of modern German social theory and social radicalism.

However ineffectual they appear to us now, the German Wars of Liberation and the Prussion Reform Era along with the Revolutions

1 It is encouraging to note that Kaethe Mengelberg, one of the most astute students of Stein's work, will soon publish a translation of his major work: Geschichte der Sozialen Bewegung in Frankreich. See, Kaethe Mengelberg, "Lorenz von Stein and his Contribution to Historical Sociology", in: Journal of the History of Ideas, Vol. XXII, 2, AprilJune, 196r. 
of 1830 were enough to create in Germany a powerful belief that the great wave of enlightened reform which had swept France would soon engulf Germany. Building on this experience, and using the categories of German philosophical idealism to give voice to their revolutionary stirrings, Stein's generation demonstrated an intense and new (for Germany) general concern with social reform, socialism and the new science of society. Lorenz von Stein as a student of law and philosophy at Kiel, Jena and, finally, Berlin, united in those two disciplines the two aspects of the most crucial political controversy of the day, the controversy concerning the need for a radical reform of the German political and legal systems. The concern began with the famous I 8 I4 debates between Savigny and Thibault as to whether or not the laws of the Germanies ought to be radically recast so as to correspond to the vast upheavals of the revolutionary era. The debate, in Stein's day, was carried on by means of the intellectual ammunition readily available in the armory of German philosophy. Still, the controversy was anything but impractical. Napoleon had recast much of German legal and political tradition through his Codes. The question remained, having cast off the tyranny of the infamous "sonin-law", was one to respect the enlightened reforms as well? The "traditionalists", following Savigny, wanted no thoroughgoing revision of the laws of the Germanies. Lorenz von Stein, along with the younger German intellectuals of the Universities, wanted a united Germany with a legal code capable of fulfilling all the promise of a liberal and constitutional monarchy; the promise which seemed to have been offered by the spirit of the Wars of Liberation and the upheavals of 1830.1

Condemning a new edition of an old classic of criminal law, Stein commented, "To the practicing jurist a law book must be a mirror of the times in which he lives and works." 2 Spiritual progress demands new law. The discussion now may seem obvious, but many of those who taught the law in Stein's day and most of those who made it disagreed. Savigny's students dominated the law faculties; he himself was appointed Prussian Minister for the Revision of Legislation in I 842. For them, the modern spirit meant Napoleonic tyranny and

1 Stein's early attitude toward politics, law reform, and philosophy can be found in the following reviews:

Lorenz Stein, Die Wissenschaft der Römischen Rechtsgeschichte, in: Hallische Jahrbücher, I 839, Numbers $201-206$.

Stein, Carl von Savigny, System des Heutigen Römischen Rechts, in: Deutsche Jahrbücher, 184r, Numbers 92-96.

Stein, Feuerbach, Lehrbuch des Gemeinen im Deutschland Giltegen Peinlichen Rechts, in: Deutsche Jahrbücher, 1842, Numbers $70-74$.

2 Stein, "Feuerbach", Number 72, p. 285. 
revolutionary terror - not the Rights of Man. Only the slow change of custom can sanction new law, they argued; to ignore ancient practice is to court anarchy.

What was original and strictly Germanic about the debate over the future of Germany was the use of the terminology of German philosophical idealism as a means of conveying the above ideas. Here is a rather extreme example from one of the early reviews of Stein:

"If we recognise Reason, or the Spirit, or the Absolute Self, or the Ego, and see how it becomes its own object as the highest knowable, we will then recognise that Reason is the highest law for all that is rational. But law is rational, and law is something determined and set down by man, therefore, Reason must set the highest norms for law, if we are to recognise in law something worthy of mankind." 1

The quotation is reminiscent of the heavy yet heady style of Hegel and Fichte: a style quite familiar to the readers of Stein's reviews. To the modern reader, Stein may seem to have said, and said awkwardly, little more than that law must be kept reasonable. To dismiss the rest, however, would be to dismiss metaphysics as simply bad style. When Stein says that Reason or the Spirit must become its own object, or that it must become conscious of itself, or even that it will realize itself, he is not merely misusing the active voice nor simply mistakenly attributing the power of personality to abstract nouns. He is expressing a common and profound moral conviction of the day. Thought itself, he is really saying, is an autonomous and mighty force, a force which will in the end prove superior to merely temporal arrangements - to that which merely exists. Spirit is the ultimate creative source. Reason, hence, will find expression in a rational system of law; Reason will become the norm for all that exists; these things will happen because the Spirit is supreme. In short, Stein was a Dialectical Idealist. And this was the metaphysical commitment which inspired the utopianism of the various radicals, reformers, left-Hegelians, and Socialists of the German Vormärz.

Hegel himself was politically a moderate, although far from reactionary. Consequently, the radical idealism which his "Philosophy of the Spirit" inspired has often been misunderstood. Philosophical idealism, with its emphasis on the supreme and ever renewed creativity of the spirit, inspired Stein with the belief that Germany would of necessity have to come to terms with the modern, revolutionary and liberal "Weltgeist". German philosophy itself, however, did not provide

1 Stein, "Römische Rechtsgeschichte", Number 201, p 1604. 
the principles and programs for these radical changes. The deterministic idealism of the Absolute Spirit unfolding itself through the epochs and eras of Western Christendom was a faith which gave the certainty that history and even the Divine were at work to make radical progress a certainty. Still, Stein (and in this he also reflects the mood of his day) felt that the terminology and precepts of German idealism were themselves not enough to guide those who wished to create a modern Germany. What is our concrete meaning he asked in one of his reviews, by our continual use of such phrases as "the realization of the Spirit", "the growth of reason", and the "ego finding itself in the non-ego"? " Such expressions of our devotion to the Absolute do not tell us how we are to translate our idealism into concrete political and social practices. With Marx, Stein became dissatisfied with a philosophy which (in one of the clichés of the day) was said to be able to interpret the world but could do nothing to transform it. Stein expressed the vague but inspired searching of his generation of young German intellectuals when he wrote:

"One feels that the old system and the old form of things no longer suffice; one works and searches for the new without finding it ... and although no one is able to name what is coming or tell us what it will be, all are convinced that the present is but a preparation for that which is itself in preparation." 2

Inspired by German philosophy, Stein turned to his study of the French Revolution with the hope that there he would find the principles and practices of the modern spirit at work. And again, Stein was merely following an impulse which led Marx, Engels, the leftHegelians and most German radicals into the study of what they regarded as the latest political and social manifestation of Hegel's Absolute Spirit. With this impulse, modern German socialism and social theory began.

The revolutions in France, the swift industrialization of England: these events made European intellectuals aware of what they came to call the "social problem" in all its aspects. Both events could only be understood as vast social movements - the Revolution as a struggle between classes; industrialism as a sweeping change in the very fabric of society. For Germans this awareness, with the events themselves or their repercussions, came late. Just as Marx became a Socialist through a study of French Utopianism and Engels through his observations of the English working class, so all German intellectuals learned from

${ }_{1}$ Stein, Ibid., Number 202, p. 1612.

2 Stein, Ibid., Number 202, p. 1613. 
the social experience of other nations. In this, Lorenz von Stein can claim to be the pioneer; he published the first thorough description of French socialism for a German audience in $1842 .^{1} \mathrm{He}$ hoped, however, to be known as more than the historian of French socialism; he hoped to be the founder of the science of society. In this hope and his consequent attempt, in the Geschichte, to carry it to fruition, he demonstrated that the Germans, whatever else they might have owed to the experience of other nations, had no need to search elsewhere for philosophy. For Stein's search for a Gesellscbaftswissenschaft was derived from his commitment to German idealism in its Hegelian form. He has, in fact, been aptly called an "Hegelian of the middle". For, as with almost every German Socialist of the day - from Marx on down - Stein attempted to form a science of society (even a scientific socialism) out of the categories and processes through which social reality was usually viewed by those under the powerful influence of the master of dialectical idealism, Hegel.

The nature of Hegel's influence on the young intellectuals of Germany has been obscured, until recent scholarship, because Hegel's political philosophy itself has been distorted so as to make it appear to be far more rightist than it was. The usual presentation of Hegel's political views does not make it seem credible that he could have so much direct influence on the early history of German radicalism and socialism. (The Hegel/Marx connection is usually, and incorrectly, seen as one in which Marx uses the dialectical form of Hegel only after "purifying" it by refuting and reversing Hegel as to substance.) Following Marcuse's excellent discussion of Hegel's political philosophy in "Reason and Revolution", we can see how gross an error it is to continue to think of Hegel even as a conservative in generally accepted nineteenth century terms - let alone a reactionary. ${ }^{2}$

To follow Marcuse, Hegel believed that "the growing antagonisms of civil society increasingly makes the social organism a blind chaos of selfish interests and necessitates the establishment of a powerful institution (the state) to control the confusion." ${ }^{3}$ Furthermore, the destruction threatening civil society was the result of the clash of economic interests, a clash which also threatened the impoverishment of the helpless, and could only be solved, Hegel suggested, by a state "capable of dominating the conflicting interests of its members." 4

${ }_{1}$ Lorenz Stein, Der Sozialismus und Kommunismus des heutigen Frankreich (Leipzig, 1842).

2 The Humanities Press, Second Edition. See also Mr. Marcuse's discussion of Stein in the same work.

3 Herbert Marcuse, op. cit., p. 2 II.

4 Ibid., p. $17^{2}$. 
Hegel also maintained that the institution of private property must be upheld although he did not intend, evidentally, to rule out the "administrative regulation" of the labor of all. ${ }^{\text {"We }}$ will find that Stein constructed his solution to the social problem out of similar elements, and his resolution was also far from conservative. Indeed, one might suggest that Hegel's position, though never fully worked out, would correspond quite easily with the views some of our more moderate and contemporary supporters of the welfare-state. Seen from the vantage point of Prussia in the first half of the nineteenth century, such a view must be called radical - certainly Marcuse's evidence shows that the Prussian government thought so. In any event, for both Hegel and his follower Stein the best resolution to the social problems of the day was to be found within a constitutional monarchy protecting the workers (broadly defined) from the consequences of the brutalities of unregulated free enterprise.

Hegel had done little, however, to integrate these general views into his more general philosophical structure. As his followers liked to think, what Hegel had done for history the left-Hegelians could now do for society. Lorenz von Stein was the first to accept this historical task of developing a pragmatic philosophy of society out of the categories of Hegelian dialectical idealism. Society was discovered; philosophical idealism was to be its prophet.

"Our time has begun to observe a series of phenomena for which one previously had no place in daily life or science.

... human knowledge has arrived at one of those discoveries which enables it to perceive behind the previously known world and its structure another more significant organism of powers and elements.

... This is society, its concept, its elements, and its movements."2

Voicing a complaint which was to become common among socialists and sociologists, Stein protested at what he regarded as the historians' penchant for mere description. Have they not given us a mere narrative of political events because they have not understood that such surface occurrences are not self-caused, but are thrust up by the laws of society; laws which themselves are generated by the powerful movements within that vast system of class and interest which is society? Stein would not make the same error. "For our purposes the single facts have little value. It is the great path of development itself that we seek." 3 Moreover, expressing another common nineteenth

1 Ibid., p. 2 I 2.

2 Lorenz von Stein, Geschichte der Sozialen Bewegung in Frankreich, I92 I, I, pp. I 1 I- 1 I 2.

3 Ibid., II, p. 57. 
century theme, Stein held that ideas become popular insofar as they are vehicles of class interest. ${ }^{1}$ For all those working within the tradition of German idealism, the thought was quite natural and was expressed by many left-Hegelians in the late forties.

All those influenced by what might be called Hegel's peculiar German form of eighteenth century deism, shared a desire to look beyond social and historical "appearances" to detect an Unterbau - a pattern of determining law generated by hidden forces. Hegel found his determining force in the self-realization of the Absolute Spirit; a more radical and anti-deist generation attempted to derive these hidden forces from the clash of concrete interests and ideas in society. After Hegel, German idealism could only be useful, in social or political analysis, as either socialism or sociology. To put it in terms current during Stein's day, theology had to give way to anthropology.

The dialectic, or the notion of progress through the clash of opposites and their ultimate resolution, is a typical product of the romantic imagination. It expresses in a formal way that sense of the contradiction between the actual and the ideal which was both the despair and the hope of the romanticists. ${ }^{2}$ As Stein once put it:

"In every man there lives a contradiction; we find it expressed in all his work and efforts, his hopes and needs; it is the contradiction between that which man, conscious of the self, would like to be, and that which he really is - between his vocation and his raality." 3

For a generation faced with finding principles for re-building society in a revolutionary era, the dialectic is useful because it expresses this contradiction and offers a formal resolution through the unity of opposites. For Stein and the left-Hegelians, reality was a struggle between opposites - the actual and the ideal. Out of this struggle must come, of course, the synthesis containing elements from both man's present environment and his ideal imaginings. Through this continual process of dialectical idealism man would, Stein hoped, finally realize his true destiny. "The destiny of man is his completion, or the realization of all those abilities which are in him..." 4 Stein's $G e^{-}$

1 Stein, Sozialismus und Kommunismus, 1848, I, p. 3-4. There is little evidence that Stein had much direct or far reaching influence over Karl Marx. Their ideas have much in common, but that is because many of their ideas were fairly common among the intellectuals of the German forties.

2 For some excellent expressions of this, see, Jacques Barzun, Classic, Romantic, and Modern, Anchor Books, 1961, pp. I $70-173$.

3 Stein, Ibid., I, p. 16.

4 Stein, Blicke auf der Socialismus und Communismus in Deutschland und ihre Zukunft, in: Deutsche Vierteljahrs Schrift. 1844, p. 7. 
schichte, then, was an attempt to illustrate this dialectical idealism through a history of France during the revolutionary era - 1789 to I 848 .

Stein's use of the dialectic was crude when compared say, with the complexities of Marx's dialectical interpretation of the laws of economics. Nevertheless, all those who used the dialectical form which the left-Hegelians abstracted and oversimplified in their hurried and inspired reading of Hegel were forced to distort considerably the subtle and ambigious processes of social change to make them fit the rigid needs of stark dialectical either/or thinking. (What we now refer to as "vulgar" Marxism, or unmodified dialectical thinking, can often be found in Marx himself in spite of the denials of many Marxists.) Dialectical thinking projects a vision of dramatic social change through the clash of opposed and opposite forces, starkly delineated and meeting in a revolutionary interplay of dialectical thrust and counterthrust. As we shall see, such a method works through the discovery of contradictions between opposed forces; the resolution of these contradictions becomes then the task of world-history.

Dialectical materialists found the revolutionary clash to take place between opposed material forces; dialectical idealists envisioned, with Stein, a clash between the two vast forces of matter and spirit, with spirit ultimately supreme. Until Marx, of course, dialectical idealism was the reigning form among left-Hegelians and Hegelians "of the middle" like Stein.

Stein's Geschichte der Sozialen Bewegung in Frankreich, then, is a history of the radical transformation of the French social and political structure from 1789 to 1848 , and it is dominated throughout by thestark categories of early dialectical idealism. As follows from the demands of dialectical idealism, Stein clearly separates the realms of matter and spirit in history. He organizes his discussion dialectically, as it were. First he described what he called the "movement towards tyranny" a product of material forces. He meant the laws of economics and class interest, the class struggle; forces which would lead, he thought, to a complete tyranny of the capitalist state. This was meant, however, as a projection, not a prediction. Spiritual forces - the "movement towards freedom" - would act as a dialectical counterforce and would ultimately prevent the victory of capitalist tyranny. The spiritual forces were, for Stein, embodied in the increasing demand for freedom and social justice as found in the political ideas of the natural law theorists, the philosophes, and finally, the French Socialists. The idea of freedom, taking root among the oppressed workers, Stein concluded, would one day clash with the tyrannical forces of capitalist 
rule. To anticipate Stein's hope, the resolution of the great contradiction between force and freedom (the synthesis) would result in what he once called a "republic of social reform".

The distortions and even fictions which result from fitting the history of society into the rationalistic mold of the dialectic are revealed most glaringly by Stein's treatment of the laws of economics. The dialectic demands stark contradictions, and this way of thinking rather than empirical observation led to the swift acceptance by Stein (and other pre-Marxian German Socialists) of a very forced version of the "progressive immiserization of the proletariat" in an ever wealthier capitalist society. ${ }^{1}$

To demonstrate the existence of what a later generation would call the inevitable contradictions of capitalism, Stein assumed that when industrialism first came to France (1800-1810, his dates) anyone with a will to work and the ability to work well could gain a reward roughly equal to his effort. Social justice, had this continued, would be a minor problem. But it could not last, Stein insisted, for the necessary laws of economics in capitalist society soon brought about conditions in which those alone who owned vast masses of capital could prosper, while those without capital were forced, regardless of ability, to become the oppressed servants of the property owners.

Stein applied his dialectical thinking to history in the following way. In the beginning of industrialism, each entrepreneur had to pay about the same costs - those of wages, production, and interest on borrowed capital - so that no one began at a serious disadvantage. There came a time, however, when so much capital had been amassed within industrial society, that new capital was not needed. Consequently, the interest rate on borrowed capital fell sharply. This convinced the capitalist (then, as defined by Stein, a simple money-lender) that he could profit more by investing in a business owned by himself than by continuing to lend at a minimal interest rate. Thus capitalists tended to become entrepreneurs. And hence, Stein added, they at once put themselves in a superior competitive position, for those who do not need to pay interest on borrowed capital can offer commodities at a price lower by the going interest rate than the price offered by any competing entrepreneur who must borrow his capital. To stay in business the entrepreneur with borrowed capital must lower his prices, but the capitalist turned entrepreneur can always go him one better. He can cut his prices until he makes no profit at all, but merely earns enough to cover costs, wages, and the going interest rate on capital; this last will be his profit. This means, Stein concluded, that

${ }^{1}$ For Stein's treatment of economics see: Geschichte, I, 42ff., I07ff.; II $2 \mathrm{ff}, 26 \mathrm{ff}$. 
the entrepreneur who pays interest on borrowed capital will make no profit at all, for his costs and wages are about the same as his wealthy competitors, and what he makes above that must be entirely absorbed by the interest payments on his capital. Assuming - as Stein did - that his own wages are part of his operating costs, the entrepreneur may be able to stay in business, but he will never be able to amortize his original loan or gain any new capital. In this manner, Stein argued, the day of the economic dominance of the great capitalist firms arrives, and from then on those who are without capital find themselves unable to attain it. As Stein concluded, "the essence of industrial society .... is the rule of capital over the entire economic life and its movements." 1

Even if one ignores Stein's failure to show that this happened between 1810 and 1830 in France, there is still much that is wrong with this all-too-simple scheme of economic change. It is nothing more than economics constructed to fit the needs of the dialectic! How can it be said, for example, that each entrepreneur had to pay "about" the same costs of production and wages from i 800 to I 8 Io? Aside from the consideration that in that "about" may lie all the difference between profit and loss, costs varied from region to region and even within the same business, and not merely because some businessmen were more able than others. Succumbing to a not uncommon delusion among economic theorists during the early nineteenth century, Stein assumed an immediately effective and automatic mechanism regulating costs, wages, and prices, without considering what an advanced state of communication and transportation within a free-market system is assumed. Again, why say that capitalists and entrepreneurs did not compete with one another as producers during the early years of the Industrial Revolution? The facts do not show that, nor do they support Stein's contention that there was a sharp decline in the interest rate because industrial society had amassed more capital than established firms could use. If this had happened, how could capitalist-manufacturers hope for profits from such a stagnant economy? Yet, even if the interest rate was so much lower than the profit rate that entrepreneurs could profit far more than mere money-lenders, it does not follow that the capitalist turned entrepreneur could compete on equal terms with established businessmen. To do so, the capitalist would have to find equally skilled labor at the same wages, build factories and buy raw materials at the same costs, and find markets equal in size to those of his competitor; and all this in competition with experienced businessmen who have come so close to reaching the limits of profitable 1 Stein, Ibid., II, p. 26. 
expansion that they have little need for new capital! All this, according to Stein, the capitalist would attempt that he might pass on the saved interest rate to his customers. For following Stein's analysis, the capitalist-entrepreneur could not seek to increase his wealth by adding entrepreneurial profit to his interest returns; rather, and in order to bankrupt his competitors, he would lower his prices until he himself would gain no more than the going interest rate on his invested capital. That is to say, in the end the capitalist would earn no more than he might have earned originally and without subjecting himself to all the effort and uncertainty of becoming a manufacturer!

Dialectical thinking, as I have said, demands sharp and unavoidable contradictions between wealth and poverty. As Stein's (and Marx's!) work attests, the so-called iron law of wages admirably meets that demand - and hence its popularity among both dialectical idealists and dialectical materialists. It provides, of course, the basic contradiction in capitalist society - an ever increasing poverty in the midst of plenty. (Vulgar Marxism at its most orthodox and to be found in Marx.) Stein's explanation of the law was far less subtle than Marx's. To Stein, the proletariat in industrial society would be forced to live at the "minimum subsistence wage" because the competition between entrepreneurs who own capital and those who don't will force the latter to lower wages to rock-bottom. The capitalist-entrepreneurs will follow suit. Stein drew the usual grim picture of the future of industrial society: to avoid being forced into the proletariat, entrepreneurs will make swindle and chicane a way of life, family life and welfare among the oppressed proletariat will be destroyed, misery and class-hatred will become the norm.

Dialectical formalism also determined Stein's reading of the class relationships of the French Revolution. Using the Constitution of I79I, Stein shows how it favored the propertied classes. Projecting this tendency, he goes on to argue that "the first national law of all movement between state and society" is that the dominant economic class will seek to capture the state for its own ends. ${ }^{1}$ The undoubted supremacy of the bourgeoisie in the July Monarchy became, for Stein, the unqualified first premise of a deductive system of class law. If nothing interferes (an important qualification as we shall see) the capitalists will establish a true Kastenstaat: workers organizations will be outlawed, the proletariat will be condemned to remain propertyless, and eventually the owners will make their rule lasting by associating the power of the state with divinity itself and "every attempt of any individual to break the class distinctions in society will become a crime against God." 2

1 Stein, Ibid., p. 49.

2 Stein, Ibid., p. 6r. 
This projected vision of the working out of the tyrannical social forces of economic law and class interest was not meant as a prediction. Stein understood this. The projection, however, is again a result of dialectical formalism because the laws of economics and class interest are in this instance treated as separate from all modifying factors. This creates a false and even dangerous impression. It gives to history a false or perhaps pseudo-scientific appearance, in that it makes historical events appear to be the result of mutually antagonistic but distinct laws of self-development clashing to produce a synthesis. The search for laws in history often ends with this error of mistaking what is a result of a process of mentally abstracting from reality for reality itself. In Stein's day - the eighteen forties - the general call among German radicals for a "scientific" socialism encouraged this false separation of "forces." For, and this is important also when dealing with Marxism, scientific socialism originally meant a socialism built on economic and social laws formulated according to the dialectic. When early German Socialists, for example, complained that the French utopians were unscientific, they meant that they had not absorbed Hegel's dialectical philosophy of history. Stein's isolation of the laws of force in society, then, did not mean that he expected the class tyranny of the owners of property to be the end of industrial society. Indeed, against the "movement toward tyranny" Stein saw all the forces of the spirit of freedom and social justice arrayed in an ultimately more powerful antithesis and antithetical movement toward freedom. The imagery of German philosophical idealism is apparent as Stein envisioned a vast struggle of freedom against tyranny on the stage of world-history. Here, the radical spirit of Fichte seems more decisive than that of Hegel himself. Stein was writing these passages in the years of revolutions - I 848 and 1849 .

Dialectical idealism, as I have said, holds the forces of the spirit to be predominant over the forces of matter - in this case the special laws of economics and class tyranny as described by Stein. Stein's idealism accounts, of course, for his lack of historical reputation among the Marxist historians of early German socialism - in spite of his use of the dialectical method. If dialectical materialism can be fairly said to relegate ideas to the realm of the relatively powerless $\dot{U}$ berbau of history, Stein may be accused of the opposite error. He seemed often to regard ideas as autonomous, self-determining and somehow independent - even organic - entities. For Hegel, the history of mind was not really what we would call the history of ideas, it was the history of the progressive self-realization of God in time. Whenever Stein speaks of the idea of freedom and equality, his style (if not his substance) shows this 
indebtedness to Hegelianism. As with the German philosophical idealists, Stein seems to assign to world historical ideas the attributes of independent being: the idea of equality flows, it develops, it grows, and it seizes. Where this is not merely style, it is metaphysical commitment. The dialectic works through the clash of independent forces, autonomous yet in conflict.

According to Stein, since the Reformation (for which all German idealists had the highest respect) the idea of equality has been the basis for all political and social thought. The destruction of ancient institutions in the sixteenth century, he argued, made it necessary to seek beyond tradition for "an absolute right above and superior to all that which was merely historical." 1 That right could only be found in man and his destiny.

"It is the person and his destiny, which, more powerful than either the state or society, makes both of them serve freedom once again. With this thought begins the second great part of the theory of the movement of state and society. It is the movement of freedom which opposes that of tyranny." 2

Stein demonstrated an unusual understanding of natural law theory when he explained that, given this standard, it was quite necessary for natural law theorists, such as Grotius and Wolff, to go beyond the historically given and derive all right and law from "natural man in the state of nature." Man and his rights (as deduced from his nature) became from then on, Stein argued, the standard by which the value of all political and social institutions are to be judged. This was the leading thought of the philosophes of the French Enlightenment, Stein continued, and it was their service to make this ultimate standard well known generally among the members of society. By so doing, they helped to give power to the dialectical forces working against the tyranny of the class state.

"One can view the last half of the eighteenth century as the epoch during which thought itself became aware that it was meant to be the true ruler of all that is, and therefore began to struggle to realize itself in all phenomena, and to express in variety the unity of thought." 3

For Stein, as for all German philosophical idealists, the French Revolution ranked second only to the Reformation as a "world historical event". It was such because throughout freedom left the realm of

1 Stein, Ibid., p. 172.

2 Stein, Ibid., p. 173.

3 Stein, Ibid., p. 172. 
"pure spirit" and became an historical reality. 'The historical approach of German philosophical idealism was basically formed out of this view of the French Revolution. Commenting on the work of the men of 1789 , Stein wrote:

"Against the right of history, they set the law of reason, and in contrast to this highest law, that which had been inherited from the past appeared purely arbitrary, brought about merely by the might of the strongest, and secured only by brute force. Who can blame the people for using their strength against the law of the strongest? In this way the new form of the state was founded and the revolution canonised." 1

Moreover, the Terror showed all Europe "what the power of an abstract principle can achieve." 2

In that mighty and excited Empire, Robespiere and Danton did not rule, rather, the power of the state was in the hands of a thought; the thought that men, equal in themselves, had been made unequal by the external relationships of an unnatural society, and that therefore the form of society was the enemy of the true destiny of man, and had to be fought to death." 3

But, in dialectical terms, the material development of social forces was not ripe for the power of the abstract principle of right and social justice to find concrete historical expression. The bourgeoisie was still the most powerful economic class; Robespierre's attempt to break down class distinctions in favor of a democratic republic was bound to fail. Political theorists began to see that society itself must be transformed if the idea of equality was to find expression. Political theory must become social theory, Stein declared, more, it must become socialism as men seek out "the last bulwark of inequality, the unequal division of goods..." 4

In his early writing, then, Stein aligned himself with socialism and saw it as the latest and best expression of the dialectical movement toward freedom.

"Socialism... was the first to know and declare the contradiction between the idea of the free personality and the rule of capital. From this knowledge, socialism has deduced the principle that work (the free activity of the personality) should be

\footnotetext{
${ }^{1}$ Stein, Ibid., p. 172.

2 Ibid., p. 29I.

3 Ibid., p. 283.

4 Ibid., p. 307.
} 
released from the rule of capital, and, in fact, should itself rule capital, which means that work alone should determine in what way income is to be divided." 1

As with all dialecticians, Stein stressed the interdependence of the dialectical forces: the very victory of the bourgeois in the French Revolution gives rise to the spread of liberal ideals among those (the workers) who find themselves excluded from benefits by the rule of capital. "Work is the conquest of nature by the activity of the free spirit", he wrote in I 849 ; the goal of society must be the just reward of work. ${ }^{2}$ Work is the mediator between spirit and matter - a view Stein had found in German idealism - it is the way in which man forces nature to submit to the demands of his spirit, and through the cunning of Reason, the demand of the Absolute as well. The goal of society as well as history, then, must be a society in which work not ownership sets the norms. The inherent radicalism of German idealism and dialectical idealism (a radicalism we have learned from the Marxists to deny) is well expressed by Stein's comment that the best form of society is "that society which produces the largest amount of goods, and at the same time gives to each the largest amount of these goods that it is possible for him to earn by his participation in the joint effort." 3

Stein's use of terminology can be misleading to those who are used to dealing with the more pragmatic and empirical philosophical tradition of the West. Stein spoke of his social ideal of a just society as the Begriff (or concept) of society. Begreifen means "to understand or comprehend", his use of this phrase shows that he did not regard his ideal as simply one man's notion of what ought to be. By calling his social ideal the Begriff of society, Stein implied that the true meaning and essence of social union itself is to be a community in which work done is to be balanced by reward received. In this way, Stein attempted to give his ideal universal sanction via what one might call an ideal typology of value. To put it another way, Stein not only gave his ideal universal sanction, he also demonstrated the Idealist's belief that the ideal, and not the given, is the truly real.

From the Begriff (or "essence") of society, Stein deduced the synthesis which would, he believed, result from the working out of the antithetical dialectical forces of tyranny and freedom. His ideal of society - that work should receive its just reward - becomes, in this

1 Stein, Volume II, p. 123.

${ }^{2}$ Lorenz Stein, Ideen zur Geschichte der Arbeit, in: Deutsche Vierteljahrs Schrift, I, I849, Section Two, p. 358 .

stein, Geschichte, Volume I, p. 20. 
way, "the final cause" of the historical and dialectical development of society. Modern socialism becomes, then, one major expression of this coming synthesis of matter and spirit. Similarly, Stein admonished any social scientist who would truly understand the history of society to "keep in mind the above organization of society as something already given, and regard all areas as included by it, so that is seems already present in every detail." 1 He who would understand the acorn must know the oak; he who would understand society must know what it is just as irresistably destined to become: nothing can illustrate more sharply the radical idealism and historical determinism of the dialectical idealists who dominated the first expression of German socialism.

Dialectical idealism differed from dialectical materialism because it assigned a crucial and powerful role to ideas and ethical principles. (This, of course, was precisely what Marx condemned in what he called "Utopianism". Stein read Marx's "Poverty of Philosophy", but much later in life when he had repudiated his own dialectical idealism and radicalism.) With Fichte and the French Utopians, therefore, Stein emphasized the revolutionary role of education in the reform of society.

Through education, he argued, the workers can begin their struggle to free themselves from the tyranny of property. The upper classes will not binder them, for they will not think their economic interests threatened by those seemingly bent only on the acquisition of "spiritual goods". Stein warned, however, that education would one day prepare the workers to share control of the state; what is more, the workers will then demand such control. For through education, they will have become aware of the idea of equality and the destiny of man. Inevitably, he insisted, the day will come when the workers will be the spiritual equals of the bourgeoisie, even though still in material bondage. "Here is the point at which the principle of freedom will come into opposition with the basis of the social order." 2 Wage slavery and unearned income will be doomed, and society itself will be destroyed if the workers, forced by the intransigeance of the bourgeoisie, turn to violence to destroy a system of law designed to prevent them from owning property. Such a revolution will be "the most dreadful, merciless, and bloodiest that men can wage, the true civil war, for in this war none will be free, and victory will offer no more comfort and hope than defeat." 3

1 Stein, Ibid., p. 2 I.

2 Stein, Ibid., p. I Io-I I I.

3 Stein, Ibid., Volume III, p. 192. 
Only the capitalists can prevent this ultimate terror, Stein continued, and to do so they must use the power of the state to aid the workers. Legislation to enforce the payment of higher wages will end the terrible effects of the iron law of wages, and with this, Stein maintained, the workers will be satisfied. In spite of all he had written about the laws of the class struggle, Stein did not doubt that the industrialists would raise wages, because - as he argued in Volume Three and for the first time - it is in the interests of the capitalists as a class to keep the workers from the semi-barbarism of the subsistence wage. Otherwise, property and capital will themselves be destroyed in the fury of revolution. Similarly, if the workers are treated fairly, they will no longer demand the abolition of private property and capital, for they will understand that it is to their interst to maintain an economic system which assures their well-being.

"When both classes, but especially the ruling and owning classes know this, when they seek their highest and most practical interest in the material liberation of the workers, rather than in their oppression and exploitation, then with this consciousness of the common interest will come the beginning of the harmony of economic life, and the beginning of true freedom." 1

After Stein's stark structure of contradictory law, this resolution (more nearly a mere recommendation) seems anticlimactic, to say the least. It is in reality simply Stein's final recognition that the laws of class and economics do not act alone, that is to say, without the constant modification of whatever forces the spirit may possess. This has the unfortunate effect, however, of condemning Stein's laws of social development to the realm of ideal typology - a favorite German device, one might add. The "laws" are only gained by a thoroughgoing process of abstraction; in the real world they do not operate "as such". Perhaps this is no worse than what the British Classical Economists were doing at the same time. In any event, Stein's "laws" of class interest and economics are intestable, unobservable, and unreal - they are intellectual devices, and not very good ones, for getting at reality. Dialectical materialists may not, in the end, have provided better insights into reality. But by projecting, in the early days of Marxism, their dialectical laws of matter as acting more or less unchallenged by ideal forces, they were not forced to project what they themselves had to regard as fiction. This may lead to vulgar Marxist literalism; Stein's approach leads to the unreal ideal typology of the Weber school of history "as if". If twentieth century social theory has

${ }^{1}$ Stein, Ibid., III, p. 203. 
done no more than rid us of the necessity of choosing one or the other, it has done much.

The inherent position, then, of all dialectical idealists (as Marx saw, and related in the second part of the Communist Manifesto) was reformist. Because Stein's belief in the power of education and moral persuasion, he joined the French utopians in condemning revolution as a social evil. It was this kind of ethical bent which Marx, of course, was determined to purge from socialism. It should be understood, however, that by throwing over dialectical idealism, Marx at the same time broke with the true spirit of German philosophy. The revisionists at the end of the century saw clearly what Stein did not. When they spoke of the power of ethics and ideas over class interest; and when they pointed out the failure of Marx's dialectical laws of economics to account for empirical phenomena within capitalism, they threw over dialectical thinking as well. ${ }^{1}$

Dialectical thinking is but one important outgrowth of the systembuilding ideologizing of the nineteenth century. It exhibited and reinforced many of the "bad habits" implicit in nineteenth century system-hunting. When applied to the study of history and society, dialecticalism makes a false and rigid separation between spirit and matter. No such "pure" forces exist, of course, and hence nineteenth century thinkers too often found themselves committed to being either materialists or idealists. Many magnificent structures of nineteenth century system-builders were merely attempts to explain away the existence of other kinds of forces still needing explanation even for those committed to their non-reality. We are all too familiar with this kind of reductionism: "Life is nothing but (say) stored sunlight." (Perhaps it is great testimony to the staying power of religion that Christian dualism should prevail even among professed anti-religionists!) In any event, Stein's dialectical idealism has as its major source of error this insistence on abstracting and treating as independent, self-developing forces the realms of matter and spirit.

Correspondingly, Stein's dialectical idealism illustrates, with its abstract determinism of "forces", another unfortunate attribute of nineteenth century system-building. Life is taken from man, as it were, and given to various bloodless abstractions - class, economic law, or the Absolute Spirit. Human activity which should be central to the study of history, seems unimportant. Symbolic of this was Stein's refusal to take politics seriously - politics became for many merely

1 In faimess to Stein, it should be mentioned that in the "fffties he decided that his Gescbicbte was a bad book, and he rejected the dialectical method along with his radicalism. See Lorenz Stein, Sozialismus in Deutschland, in: Gegenwart, 1852, VII, p. 561. 
the surface phenomena thrust up by powerful but hidden forces. This refusal to take politics at face value has had the curious result of turning academics who study history and political science into relative ignoramuses when confronted with sheer politics. It also leads to the identification of profound thinking with the discovery of laws and forces "below the surface" of ordinary events. One is "profound" or "deep" to the extent that one can (usually via abstract terms in the passive voice) lay claim to having gone into the depths below the surface. Otherwise, one is merely superficial. Hence the German tradition, still falsely admired, of profound nonsense. Stein's Gescbichte fits this description. (Stein himself later complained that it was a hybrid of history and misconceived dialectical science. See last footnote.) History dialectically viewed, ceases to be the life of man and human institutions and behavior; it becomes the career in time of an Absolute - perhaps the development of the means of production, perhaps the Absolute Spirit. One gains a system, only to lose man.

The influence of dialectical thinking (idealistic or materialistic) has ceased to be felt much in the West. Stein's work is therefore of interest mainly to those who would be aware of one more interesting example of the spirit of system in the nineteenth century. Dialectical thinking, as crucial as it was in the early days of sociology and socialism, is superseded and rightly by what one can only call a more careful and flexible sense of reality and a greater awareness of the complexities of historical judgement. The various pragmatisms of our time take events as they find them, if not at face value. The forced distortions of men like Stein and the various left (and right) Hegelians as well as Marx himself may have been fruitful but they can no longer stand without serious modification. The many discussions of the various forms of the dialectic will benefit from an awareness of Stein's work, however, for his Geschichte der Sozialen Bewegung in Frankreich will remain to remind us of the existence of dialectical idealism as the first form of modern German socialism as well as a unique example of German pre-Marxian utopian thought. 